\title{
Effect of Soccer Foot Pressure on Pressure Distributions
}

\author{
Ahmet Uzun ${ }^{1}$, Latif Aydos ${ }^{2}$, Metin Kaya ${ }^{2}, \mathrm{H}$. Ahmet Pekel ${ }^{2}$, Ulunay Kanatli ${ }^{2}$ \\ ${ }^{1}$ Physical Education and Sport Department, AKEF, Necmettin Erbakan University, Turkey \\ ${ }^{2}$ Sport Sciences Faculty, Gazi University, Turkey \\ ${ }^{3}$ Department of Orthopaedics and Traumatology, Gazi University, Turkey \\ Correspondence: Mehmet Yıldız, Turkey.
}

Received: March 25, 2018

Accepted: April 10, $2018 \quad$ Online Published: April 23, 2018

doi:10.11114/jets.v6i6.3118

URL: https://doi.org/10.11114/jets.v6i6.3118

\begin{abstract}
The aim of this research is to investigate the effect of playing soccer for a long time in for professional soccer players regarding sole pressure. Despite the increasing prevalence of new methods developed in the footpad pressure measurement in recent years, our knowledge about pressure distribution of the footplate is still insufficient, especially for sportsmen (Ford et al., 2006). Plantar pressure analysis system (EMED-SF) was used in the study. Statistically significant differences between the study groups were examined using the non-parametric Mann-Whitney $\mathrm{U}$ test. According to the results of the research, there was no statistical difference between the experimental and control groups in terms of physical characteristics. However, significant results were found at (0.01-0.05) level in the beginning and grand total of heel medial, heel lateral, 1,2,3,4,5 metatars in the maximal force comparisons applied to the right and left foot contact area and the floor.
\end{abstract}

Keywords: soccer foot pressure, pressure distributions

\section{Introduction}

Football is one of the world's most popular sports, with 265 million regular football players worldwide. While the average world population is playing football regularly on average about 4.1 percent, only 0.03 percent of them (about 110,000 athletes) are professional male football players. (Kunz, 2007). The age of onset of football in the world is about six (Coté, Horton, MacDonald \& Wilkes, 2009) and the age of starting football is between five and 12 for elite and non-elite athletes (Ford, Ward, Hodges, \& Williams, 2009). The tempo in football is gradually increased during childhood. Adult-type walking is formed in children aged seven to nine (Keen, 1993) and usually coincides with the beginning of the football game. It is known that intense sport activities, especially those that started in the pre-developmental period, affect the normal movement system and form walking patterns specific to each sport (Renström\&Johnson,1985).

With today's technological development, the use of gait analyzes is becoming widespread in research and clinical practice in the musculoskeletal system for diagnosis, treatment planning, and measurement and monitoring of outcome (Simon, 2004). However, many intra-articular biomechanical studies have been carried out by making kinetic and kinematic measurements besides the clinical use of the walking analysis and adding pressure measurements to them. Especially today, pedobarography is widely used for researching normal foot space (Kanatl1, Yetkin, Songür, Öztürk, \& Bölükbaş1, 2006) It is deduced that the contact of the sole of the foot may be caused by changes in the sole of the foot with different intensities and different shapes. Specifically, the fact that the performance of the player is dependent on the shoe variables also makes determination of the effect of the foot on the foot important for both comfort and health. The fact that football is a game played on the feet increases the importance of this work.

\section{Purpose of Study}

The purpose of this study is to investigate the effect of soccer training on footpad pressure distributions for years.

\section{Materials and Methods}

The consent for this study was given by T.C. Gazi University-Faculty of Medicine Local Ethics Commission's gave with the date of 25th February 2008 and with decision of 074 without drug for clinic studies has been done. All of attendants were informed verbally and in writing about the purpose of study and the evaluation methods to be applied. Approval forms were taken from all of attendants. Fifteen players ( $22,65 \pm 2,6$ yaş, $174,2 \pm 5,6 \mathrm{~cm}$ boy,71,2 $\pm 4,8 \mathrm{~kg}$ 
body weight, $23,21 \pm 1,4 \mathrm{~kg} / \mathrm{m}^{2}$ BMI) who play in Super League teams which is the highest league of Turkish Football Federation and fifteen volunteers( $22,6 \pm 1,6$ age, $177,3 \pm 5,4 \mathrm{~cm}$ height, $72,1 \pm 3,3 \mathrm{~kg}$ body weight, $23,01 \pm 1,9 \mathrm{~kg} / \mathrm{m}^{2}$ BMI ) for control group were included in the study. It has been specified that qualified soccer players start football approximately at the age of nine.

Players who underwent foot or ankle surgeons in the last six months of the study and who had previous foot fractures were not included in the study.

The pedobarographic measurements of the foot volunteers were carried out using the plantar pressure analysis system, EMED-SF (Novel GmbH, Munich, Germany) in the walking laboratory of GÜTF Orthopedics and Traumatology AD. This system is mounted on a $7 \times 1 \mathrm{~m}$ wooden platform and includes a platform of $44.4 \times 22.5 \mathrm{~cm}$ with a sampling rate of 71 $\mathrm{Hz}$ and two receivers in $\mathrm{cm}^{2}$ covered with thin skin.

Participants walked freely before pressing the foot pedobarogram in the 7-meter walking band, and the region where the measurement was made is not specified. The measurements were taken with bare feet and two dynamic measurements for each foot.

The foot floor is divided into 11 regions called masks and each region contact area $\left(\mathrm{cm}^{2}\right)$ is evaluated in terms of maximal force (N/ cm2) (Figure-1). The right and left feet were evaluated separately and the mean of the two received data was taken.

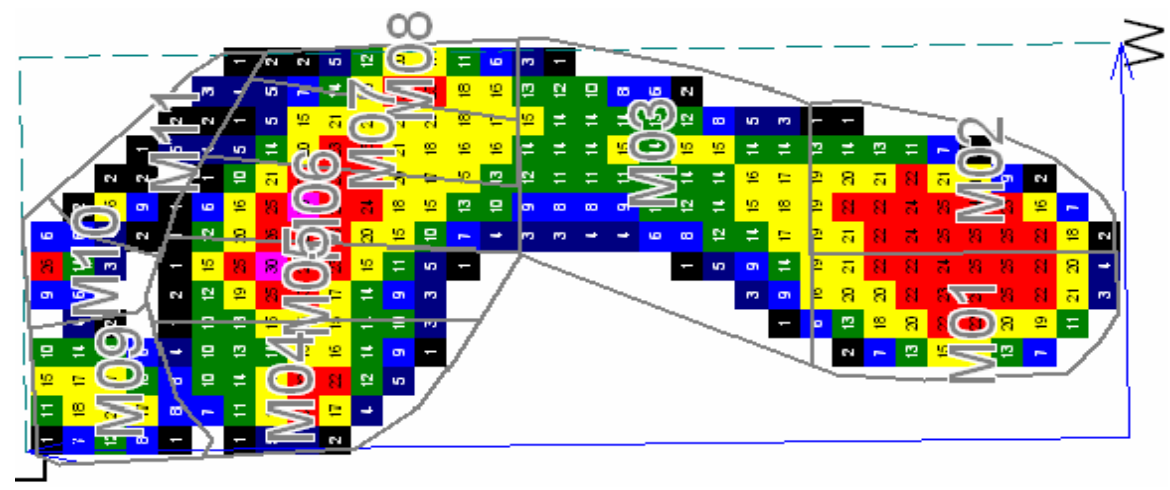

Figure 1. Mask zones in pedobaography (M01: medial of heel, M02: lateral of heel, M03: mid-foot, M04: 1st metatarsal head, M05: 2nd metatarsal head, M06: 3rd metatarsal head, M07: 4th metatarsal head, M08: 5th metatarsal head, M09: pollex M10: 2nd finger, M11: 3rd 4th and fifth fingers)

\section{Statistical Evaluation}

Analysis of the data was made in SPSS 18 package program. Non-parametric Mann Whitney U test for statistically significant difference between the mean of the subjects and the control group; P $<0.01-0.05$ significance level with 95 percent confidence interval was accepted in the measurements.

\section{Results}

Table 1. The physical properties of football players (1) and normal population (2) in this study

\begin{tabular}{|c|c|c|c|c|c|c|c|c|c|c|}
\hline \multirow[b]{2}{*}{ Variables } & \multirow[b]{2}{*}{ iroup } & \multirow[b]{2}{*}{ Mean } & \multirow[b]{2}{*}{ S.D } & \multirow[b]{2}{*}{$\mathrm{X} 1$ - X2 } & \multirow[b]{2}{*}{ Min. } & \multirow[b]{2}{*}{ Maks. } & \multirow[b]{2}{*}{ t. } & \multicolumn{3}{|c|}{ Mann-Whitney } \\
\hline & & & & & & & & $\mathbf{P}$ & $\mathbf{U}$ & \multirow{3}{*}{$\frac{\mathbf{P}}{-, 978}$} \\
\hline \multirow{3}{*}{ Age (year) } & 1 & 22,650 & 2,641 & \multirow[b]{2}{*}{0,050} & 19,00 & 27,00 & \multirow{2}{*}{, 072} & \multirow{2}{*}{0,29} & \multirow{2}{*}{199,00} & \\
\hline & 2 & 22,600 & 1,602 & & 20,00 & 26,00 & & & & \\
\hline & 1 & 174,20 & 5,671 & \multirow{2}{*}{$-3,100$} & 169,00 & 187,00 & \multirow{2}{*}{$-1,763$} & \multirow{2}{*}{, 725} & \multirow{2}{*}{110,00} & \multirow{2}{*}{, 0150} \\
\hline Height (cm) & 2 & 177,30 & 5,449 & & 164,00 & 183,00 & & & & \\
\hline \multirow{3}{*}{ Body Weight (kg) } & 1 & 71,200 & 4,829 & \multirow{2}{*}{,- 900} & 68,00 & 75,00 & \multirow{2}{*}{,- 682} & \multirow{2}{*}{, 158} & \multirow{2}{*}{138,000} & \multirow{2}{*}{,0920 } \\
\hline & 2 & 72,100 & 3,385 & & 64,00 & 76,00 & & & & \\
\hline & 1 & 23,211 & 1,415 & \multirow{2}{*}{,201 } & 21,00 & 26,20 & \multirow{2}{*}{, 375} & \multirow{2}{*}{,264 } & \multirow{2}{*}{186,000} & \multirow{2}{*}{,705 } \\
\hline BMI $\left(\mathrm{kg} / \mathrm{m}^{2}\right)$ & 2 & 23,010 & 1,935 & & 19,11 & 26,39 & & & & \\
\hline
\end{tabular}
$* * \mathbf{P}<0.01 * \mathbf{P}<0.05$

In Table 1, There was no significant difference in the age, height, body weight and body mass index averages of footballers and control groups at $\mathrm{P}<0.01$ level. The lack of significance of differences between the groups suggests a homogeneous distribution.

In Table 2, The difference between the mean values of peak pressure comparisons of the football players and the control group in the contact area of the left and right legs was significant at the heel medial and heel lateral in both legs, right at the beginning of the second leg of the metatarsal and left leg at the first leg of the metatarsal $(\mathrm{P}<0.01-0.05)$. 
Table 2. The Comparison of the Right and Left Foot Peak Pressure of subjects (1) and control group (2) in the study

\begin{tabular}{|c|c|c|c|c|c|c|c|c|c|}
\hline \multirow[b]{2}{*}{ Variables } & \multirow[b]{2}{*}{ Group } & \multicolumn{4}{|c|}{ Right Foot } & \multicolumn{4}{|c|}{ Left Foot } \\
\hline & & Mean & S.D & $\begin{array}{c}\text { Mann-Whi } \\
\text { tney U }\end{array}$ & $\mathbf{P}$ & Mean & S.D & $\begin{array}{c}\text { Mann-Whi } \\
\text { tney U }\end{array}$ & $\mathbf{P}$ \\
\hline \multirow[t]{2}{*}{ Total Foot - TOTAL } & 1 & 61,52 & 26,64 & \multirow{2}{*}{153,500} & \multirow{2}{*}{,208 } & 56,52 & 10,92 & \multirow{2}{*}{88,500} & $* *$ \\
\hline & 2 & 70,52 & 26,29 & & & 76,35 & 25,77 & & 007 \\
\hline \multirow[t]{2}{*}{ MO1: Medial Heel } & 1 & 33,90 & 5,881 & \multirow{2}{*}{76,500} & $* *$ & 37,05 & 10,39 & \multirow{2}{*}{98,500} & * \\
\hline & 2 & 46,37 & 13,96 & & ,001 & 46,40 & 16,59 & & ,017 \\
\hline \multirow[t]{2}{*}{ MO 2: Lateral Heel } & 1 & 32,60 & 5,713 & \multirow{2}{*}{81,500} & $* *$ & 33,00 & 6,026 & \multirow{2}{*}{99,500} & * \\
\hline & 2 & 41,87 & 10,00 & & ,001 & 39,20 & 7,836 & & ,018 \\
\hline \multirow[t]{2}{*}{ MO 3: Medial Foot } & 1 & 15,02 & 5,708 & \multirow{2}{*}{183,500} & \multirow{2}{*}{,655 } & 14,33 & 4,098 & \multirow{2}{*}{158,500} & \multirow{2}{*}{, 529} \\
\hline & 2 & 15,02 & 4,697 & & & 15,05 & 4,260 & & \\
\hline MO 4: Foot & 1 & 23,95 & 8,159 & \multirow{2}{*}{149,000} & \multirow{2}{*}{,167 } & 22,41 & 8,011 & \multirow{2}{*}{112,500} & \\
\hline $1^{\text {st }}$ Metatarsal Head & 2 & 35,25 & 22,91 & & & 29,72 & 13,91 & & ,048 \\
\hline MO 5: Foot & 1 & 45,97 & 23,62 & \multirow{2}{*}{96,000} & $* *$ & 41,91 & 8,29 & \multirow{2}{*}{126,000} & \multirow{2}{*}{, 114} \\
\hline $2^{\text {nd }}$ Metatarsal Head & 2 & 65,25 & 27,53 & &, 005 & 60,35 & 29,45 & & \\
\hline MO 6: Foot & 1 & 44,52 & 20,44 & \multirow{2}{*}{136,000} & \multirow{2}{*}{,083 } & 44,05 & 10,95 & \multirow{2}{*}{126,000} & \multirow{2}{*}{, 114} \\
\hline $3^{\text {rd }}$ Metatarsal Head & 2 & 49,00 & 13,23 & & & 55,60 & 21,42 & & \\
\hline MO 7: Foot & 1 & 34,42 & 18,03 & \multirow{2}{*}{174,000} & \multirow{2}{*}{,482 } & 32,19 & 13,47 & & \\
\hline $4^{\text {th }}$ Metatarsal Head & 2 & 28,67 & 5,62 & & & 32,82 & 10,43 & 175,000 &, 884 \\
\hline MO 8: Foot & 1 & 31,22 & 25,28 & & & 28,44 & 16,52 & & \\
\hline $5^{\text {th }}$ Metatarsal Head & 2 & 28,50 & 10,36 & 163,500 &, 323 & 40,85 & 25,30 & 125,500 &, 111 \\
\hline MO 9:Foot & 1 & 36,15 & 17,08 & & & 37,61 & 16,13 & & \\
\hline Thumb & 2 & 41,67 & 21,33 & 169,500 & ,409 & 48,55 & 24,02 & 125,500 &, 111 \\
\hline MO 10: Foot & 1 & 20,82 & 8,407 & & & 16,66 & 4,931 & & \\
\hline $2^{\text {nd }}$ Toes & 2 & 21,12 & 12,98 & 181,500 & ,617 & 18,27 & 8,836 & 165,500 & 671 \\
\hline MO 11: Foot & 1 & 15,32 & 7,847 & & & 12,50 & 5,210 & & \\
\hline $3^{\text {rd }}, 4^{\text {th }}, 5^{\text {th }}$ Toes & 2 & 13,32 & 8,206 & 179,000 & ,570 & 10,42 & 7,056 & 136,000 & , 198 \\
\hline
\end{tabular}

$* * \mathbf{P}<0.01 * \mathbf{P}<0.05$

Table 3. The Comparison of the Right and Left Foot Maximum Pressure Strength [N] of subjects (1) and control group (2) in the study $\left[\mathrm{N} / \mathrm{cm}^{2}\right]$

\begin{tabular}{|c|c|c|c|c|c|c|c|c|c|}
\hline \multirow[b]{2}{*}{ Variables } & \multirow[b]{2}{*}{ Group } & \multicolumn{4}{|c|}{ Right Foot } & \multicolumn{4}{|c|}{ Left Foot } \\
\hline & & Mean & S.D & Mann-Whitney U & $\mathrm{P}$ & Mean & S.D & Mann-Whitney U & $\mathrm{P}$ \\
\hline \multirow{3}{*}{ Total Foot - TOTAL } & 1 & 14,82 & 2,099 & \multirow{2}{*}{109,000} & \multirow{2}{*}{$*, 014$} & 14,66 & 1,664 & \multirow{2}{*}{75,500} & $* *$ \\
\hline & 2 & 17,22 & 2,905 & & & 17,69 & 3,112 & & ,002 \\
\hline & 1 & 19,95 & 2,926 & \multirow{2}{*}{91,000} & \multirow{2}{*}{$: *, 003$} & 20,03 & 4,189 & \multirow{2}{*}{97,500} & * \\
\hline \multirow[t]{2}{*}{ MO1: Medial Heel } & 2 & 23,97 & 4,335 & & & 23,97 & 5,665 & & ,016 \\
\hline & 1 & 17,64 & 2,538 & \multirow{2}{*}{139,000} & \multirow{2}{*}{,099 } & 17,43 & 2,214 & \multirow{2}{*}{125,000} & \multirow{2}{*}{, 108} \\
\hline \multirow[t]{2}{*}{ MO 2: Lateral Heel } & 2 & 19,94 & 3,745 & & & 19,19 & 3,434 & & \\
\hline & 1 & 5,59 & 2,029 & \multirow{2}{*}{153,500} & \multirow{3}{*}{,208 } & 5,73 & 1,806 & \multirow{2}{*}{155,000} & \multirow{3}{*}{,465 } \\
\hline \multirow[t]{2}{*}{ MO 3: Medial Foot } & 2 & 6,05 & 1,522 & & & 6,07 & 1,640 & & \\
\hline & 1 & 11,93 & 3,972 & \multirow[b]{2}{*}{129,000} & & 11,42 & 4,533 & \multirow[b]{2}{*}{119,000} & \\
\hline \multirow{2}{*}{$\begin{array}{l}\text { MO 4: Foot } \\
1^{\text {st }} \text { Metatarsal Head }\end{array}$} & 2 & 15,88 & 6,619 & & $*, 050$ & 14,56 & 4,396 & &, 074 \\
\hline & 1 & 23,34 & 4,730 & \multirow{3}{*}{110,000} & \multirow{3}{*}{$*, 015$} & 22,65 & 3,914 & \multirow[b]{2}{*}{115,000} & * \\
\hline \multirow{2}{*}{$\begin{array}{l}\text { MO 5: Foot } \\
2^{\text {nd }} \text { Metatarsal Head }\end{array}$} & 2 & 28,64 & 7,638 & & & 28,78 & 9,509 & &, 050 \\
\hline & 1 & 22,12 & 5,347 & & & 22,16 & 4,505 & & * \\
\hline $\begin{array}{l}\text { MO 6: Foot } \\
3^{\text {rd }} \text { Metatarsal Head }\end{array}$ & 2 & 23,15 & 4,255 & 158,000 & ,256 & 26,65 & 7,704 & 113,000 &, 050 \\
\hline & 1 & 14,67 & 4,702 & & & 14,84 & 5,045 & & \\
\hline $\begin{array}{l}\text { MO 7: Foot } \\
4^{\text {th }} \text { Metatarsal Head }\end{array}$ & 2 & 14,64 & 2,893 & 190,000 & ,787 & 16,15 & 4,693 & 148,000 & ,349 \\
\hline & 1 & 11,89 & 6,857 & & & 11,89 & 6,857 & & \\
\hline $\begin{array}{l}\text { MO 8: Foot } \\
5^{\text {th }} \text { Metatarsal Head }\end{array}$ & 2 & 11,38 & 3,170 & 182,000 & ,626 & 11,38 & 3,170 & 123,000 & ,096 \\
\hline & 1 & 13,73 & 4,507 & & & 13,73 & 4,507 & & \\
\hline $\begin{array}{l}\text { MO 9:Foot } \\
\text { Thumb }\end{array}$ & 2 & 14,91 & 4,740 & 172,000 & ,449 & 14,91 & 4,740 & 123,000 & ,096 \\
\hline & 1 & 9,02 & 2,697 & & & 9,02 & 2,697 & & \\
\hline $\begin{array}{l}\text { MO 10: Foot } \\
2^{\text {nd }} \text { Toes }\end{array}$ & 2 & 9,44 & 3,764 & 198,000 & ,957 & 9,44 & 3,764 & 168,500 & ,737 \\
\hline & 1 & 5,27 & 2,250 & & & 5,27 & 2,250 & & \\
\hline $\begin{array}{l}\text { MO 11: Foot } \\
3^{\text {rd }}, 4^{\text {th }}, 5^{\text {th }} \text { Toes }\end{array}$ & 2 & 5,54 & 2,970 & 193,000 &, 850 & 5,54 & 2,970 & 145,500 & ,313 \\
\hline
\end{tabular}


** $\mathbf{P}<0.01 * \mathbf{P}<0.05$

In Table 3, The difference between the mean values of the maximal maximal pressures of the football players in the right and left foot contact area was found to be significant in the right and left foot total, in the heel medial and in the lower 2nd metatarsal head ( $\mathrm{P}<0.01-0.05)$.

Table 4. The Comparison of the Right and Left Foot Time-Pressure Integral [N] of subjects (1) and control group (2) in the study

\begin{tabular}{|c|c|c|c|c|c|c|c|c|c|}
\hline \multirow[b]{2}{*}{ Variables } & \multirow[b]{2}{*}{ Group } & \multicolumn{4}{|c|}{ Right Foot } & \multicolumn{4}{|c|}{ Left Foot } \\
\hline & & Mean & S.D & ann-Whitney U & S.D & Mean & S.D & Iann-Whitney U & S.D \\
\hline \multirow[b]{2}{*}{ Total Foot - TOTAL } & 1 & 22,45 & 5,838 & \multirow{2}{*}{132,000} & \multirow{2}{*}{,066 } & 20,54 & 2,799 & \multirow{2}{*}{81,000} & \multirow{2}{*}{$* *, 004$} \\
\hline & 2 & 27,22 & 8,740 & & & 27,70 & 8,469 & & \\
\hline \multirow[b]{2}{*}{ MO1: Medial Heel } & 1 & 7,32 & 1,940 & \multirow{2}{*}{79,000} & \multirow{2}{*}{$* *, 001$} & 8,18 & 2,060 & \multirow{2}{*}{129,000} & \multirow{2}{*}{,136 } \\
\hline & 2 & 10,69 & 3,304 & & & 10,54 & 5,226 & & \\
\hline \multirow[b]{2}{*}{ MO 2: Lateral Heel } & 1 & 7,02 & 1,776 & \multirow{2}{*}{68,500} & \multirow{2}{*}{$* *, 000$} & 7,57 & 1,699 & \multirow{2}{*}{140,500} & \multirow{2}{*}{,248 } \\
\hline & 2 & 9,86 & 2,474 & & & 9,05 & 3,071 & & \\
\hline \multirow{3}{*}{ MO 3: Medial Foot } & 1 & 4,31 & 1,684 & \multirow{2}{*}{150,000} & \multirow{2}{*}{,176 } & 4,13 & 1,409 & \multirow{2}{*}{145,000} & \multirow{2}{*}{,306 } \\
\hline & 2 & 4,78 & 1,755 & & & 4,51 & 1,597 & & \\
\hline & 1 & 6,43 & 2,067 & \multirow[b]{2}{*}{117,000} & \multirow[b]{2}{*}{$*, 025$} & 6,12 & 2,196 & \multirow[b]{2}{*}{93,000} & \multirow[b]{2}{*}{$*, 010$} \\
\hline \multirow[t]{2}{*}{$\begin{array}{l}\text { MO 4: Foot } \\
1^{\text {st }} \text { Metatarsal Head }\end{array}$} & 2 & 10,08 & 5,804 & & & 8,43 & 3,387 & & \\
\hline & 1 & 11,91 & 5,194 & \multirow[b]{2}{*}{110,000} & \multirow[b]{2}{*}{$*, 015$} & 10,77 & 2,575 & & \\
\hline $\begin{array}{l}\text { MO 5: Foot } \\
2^{\text {nd }} \text { Metatarsal Head }\end{array}$ & 2 & 16,42 & 5,834 & & & 15,93 & 6,309 & 94,000 & $*, 012$ \\
\hline & 1 & 12,68 & 6,603 & & & 11,82 & 3,598 & & \\
\hline $\begin{array}{l}\text { MO 6: Foot } \\
3^{\text {rd }} \text { Metatarsal Head }\end{array}$ & 2 & 14,46 & 3,957 & 128,000 & $* *, 050$ & 15,76 & 5,548 & 109,500 & $*$ *,039 \\
\hline & 1 & 9,93 & 5,216 & & & 8,99 & 3,337 & & \\
\hline $\begin{array}{l}\text { MO 7: Foot } \\
4^{\text {th }} \text { Metatarsal Head }\end{array}$ & 2 & 9,092 & 2,564 & 182,500 & ,636 & 10,25 & 3,445 & 144,000 & 293 \\
\hline & 1 & 8,45 & 5,753 & & & 7,26 & 4,351 & & \\
\hline $\begin{array}{l}\text { MO 8: Foot } \\
5^{\text {th }} \text { Metatarsal Head }\end{array}$ & 2 & 7,82 & 2,804 & 189,000 & ,766 & 10,29 & 5,769 & 119,000 & ,075 \\
\hline & 1 & 8,34 & 4,665 & 161,500 & ,298 & 7,52 & 3,428 & 82,000 & \\
\hline $\begin{array}{l}\text { MO 9:Foot } \\
\text { Thumb }\end{array}$ & 2 & 11,01 & 7,306 & & & 11,55 & 5,220 & & $* *, 004$ \\
\hline & 1 & 3,97 & 2,015 & & & 3,16 & 1,194 & & \\
\hline $\begin{array}{l}\text { MO 10: Foot } \\
2^{\text {nd }} \text { Toes }\end{array}$ & 2 & 4,94 & 3,711 & 188,000 & ,745 & 4,02 & 2,164 & 139,500 & ,236 \\
\hline & 1 & 2,81 & 1,409 & & & 2,17 & ,729 & & \\
\hline $\begin{array}{l}\text { MO 11: Foot } \\
3^{\text {rd }}, 4^{\text {th }}, 5^{\text {th }} \text { Toes }\end{array}$ & 2 & 3,42 & 2,612 & 190,000 & ,787 & 2,45 & 1,788 & 172,000 & ,815 \\
\hline
\end{tabular}

In Table 4, The pressure-time integral is the heel medial, bilateral lateral, 1,2, and at the beginning of the third metatarsal were significant $(\mathrm{P}<0.01-0.05)$ (Table 4).

\section{Discussion}

Soccer fields consist of sand, soil, natural clay and synthetic game surface (NFLPA, 2006). The results of the slalom test on 17 male soccer players and the effects of the natural and synthetic grass field surface on the soles of the foot in the shoe were investigated. Significant relationships were found between the different regions of the foot and the two field surfaces. The game determined that the field surface significantly affected the pressure distribution on the soles of the foot, the largest relative loading on the synthetic grass and the medial foot front area, and the more frequently observed injuries on the natural grass surface. They found that stress fractures due to repeated eversion movements, Jones fractures, and lateral peak loads were on the grass (Ford et al., 2006). Eils, Streyl, Linnenbecker, Thorwesten, Volker, \& Rosenbaum, found that there was a significant relationship between the specific movements for football and the pressure distribution within the foot floor, and that there was no change in the pressure parameters between the state of the football field and the pressure distribution within the footwear (2004). In studying the pressure distribution of the sole in three different technical applications consisting of inner side pass, outer side pass and acceleration movements which are prevented by the quickness test to footballers, the outer side pass increases the pressure in the outer side part of the foot, inside and front part in the inner side pass (Queen, 
Haynes, Hardaker, \& Garrett, 2007). In our study, the differences between the heel medial and heel lateral feet on the right foot and the metatarsal head on the left foot were significant in the comparison between the peak pressure values of the contact zone and the contact zone of the professional footballers and control group (Table 2). It is available in similar studies where Plantar pressure analysis system is used. In the study of 25 professional basketball players and 25 male volunteers who were investigated on the effect of professional basketball players, the comparison of right and left foot total peak pressure showed that basketballs had more right 1st leg metatars head and bigger thumb than 4th metatars head control group (Uzun, 2012). Eils and his fellow reserchers (2002) reported that while 40 healthy (25.3 years, $70.8 \mathrm{~kg}$ and $176.5 \mathrm{~cm}$ ) individuals had similar results between the distribution of peak pressure distributions and those of basketball players, they were lower than those of control group (Eils, Nolte, Tewes, Thorwesten, Völker \& Rosenbaum, 2002). In the study in which the effect of wrestling on the soles of the feet was investigated, the left foot sum of the peak pressure values, heel medial, heel lateral, 2,3,5. metatars heads and left foot sum, right foot heel medial, heel lateral, right foot 2,3,5. metatars reported that the differences in heads were more in wrestlers than in wrestlers (Aydos, 2011). It was founded that the footballers in the study generally have higher values of the right foot peak pressure values on the left. One of the most important reasons for this is the use of professional footballers of their dominant legs. Professional footballers have significantly lower values in heel medial and lateral heel in both legs, and this difference is most pronounced in this part of the foot, as more active use of the frontal parts in the movements in the game. Especially in all contact areas on the right foot, only the 5th Metatars head is higher than the non-sports individuals and all other values are lower. This can be explained by the more active use of the right leg dominated by the left leg in the training and in the side passes in the matches and in the outward fast turns. There are some other resultes. Age average 18,80 $\pm 2,2$ years 22 women participated in the football and the effect of football on the base of the foot was investigated in the study of the right foot with the head of the left metatarsal 1.2.3.4. the peak pressure values at the beginning of the metatars and on the 3-4-5th foot fingers were significantly higher in female soccer players (Uzun, 2013). The most important reason why female soccer players are higher than professional sports players in terms of their peak pressure values is because of the ground of the training and games they play on. Because while professional male soccer players continue to work on the field consisting of turf ground, female soccer players are working on synthetic or carpet field.

In the study, the mean maximal pressure was found to be low in the heel medial and the second metatarsal head in the soccer players (Table 3). The closer the front of the foot is, the lower the difference between the groups seems to be. In particular, this means that the mean maximal pressures in the body balance are important in both groups. In the mean maximal pressure values of the female soccer players, the right foot is at the head of the left metatarsal with the 2nd metatarsal head (Uzun, 2013) 2nd and 3rd metatars heads were found to be lower in the control group of the wrestlers, left foot sum, heel medial, 2.3 and 5 metatars heads were higher than the non-sports individuals (Aydos, 2011). Plantar pressures of the sole-contacting parts of the foot are measured during these movements, in which the 25-year-old soccer player participates in a movement involving running, walking, shooting, dribbling and maneuvering using the pedal mobile system. At the end of the study, it was determined that the pressure values during walking and running were close to normal values (Eils, Streyl, Linnenbecker, Thorwesten, Volker, \& Rosenbaum., 2004). In the comparison of mean maximal pressures of the right and left feet of the basketball players, basketballs were reported to have a higher first head of metatarsal head and a smaller head of the right foot and a higher third and fourth head of the right leg than the control group (Uzun, 2012). There is a strong relationship between the maximal pressure increase at the base of the foot and the excessive shaking of the body to the right and to the left, weak balance, weakening of the sensory functions of the lower members, deterioration and aging of the lower members (Lord, Mclean, \& Stathers, 1992). Foot pressures caused by unbalanced anatomical positions are the cause of physiological disturbances in the human body and muscle joint system. These constant recurrent abnormalities are also a direct cause of spinal disorders, and a direct correlation is found between the increase in scoliosis and the pressure increase in the various areas of the footpad (Park, Noh, Jang, Yu, Park, \& Choi, 2009). These studies also show that there is a strong relationship between equilibrium and foot pressure. In our study, it can be seen that the mean maximal pressure values are closer to the individuals who do not exercise than the peak pressure values, especially the similarity is very high in the front part of the foot. We see similar results in our work, and we can say that changes in the balance foot are the result of the efforts of the footballers to keep themselves in the games and in the training sessions.

In the pressure-time integration in the study groups, it is seen that there are significant differences in the results of right foot heel medial and heel lateral after 1, 2 and 3 metatars heads in both feet (Table 4).During walking, it is shown that different footpads have different pressure fields and time pressure integrals (Chen, Nigg, \& Dekoning, 1994). (Chen, Nigg, \& Dekoning, 1994). Fong, Mao, Li, \& Hong (2008), in a comparative study on nine slippery and non-slippery surfaces of nine soles of the foot base evaluated by 10 trial gait and pressure time interalina on the walking path on five meter long dry, sandy, wet and oily wood, While the pressure time integral increased by 79 percent and the lateral fingers by 34 percent Peak pressure in the medial and lateral heel decreased by 20-24. On the oiled floor, the peak pressure was increased from the outside, while the pressure time integral increased from the inside to the outside. The results of this study show that the pressure time integral of peak pressure gait can be affected by other variables (age, height, body weight) (Fong, Mao, Li, 
\& Hong, 2008). In female soccer players, the time pressure integrals of the football players in the heel medial, the heel lateral, the heel lateral, the second, and the fifth metatarsal heads are lower than the control group (Uzun, 2013). In the study of four different movements of the plantar areas and pressures of the sole, the peak pressure and pressure-time integrals of the sole during 15 male soccer players running, maximal speed running to the side, jumping and turning with $45^{\circ}$ angle motion were investigated. At the end of the study it was stated that the inclination of the lateral sides of the midsole could be a preventive factor in the injury of the footballers and that the soles could adapt to flex and bend their feet. In addition, in the design of the crampons and special muscle training, the risk of injury and the reduction of the pressure on the soles of the feet should be taken into consideration (Wong, Chamari, Wisløff, \& Hong, 2007). Studies support our findings. It is expected that the time pressure integrals of footballers will generally be lower.

This is because fast and quick shifting from the moment when the sole of the soccer player touches the ground can be explained by the work done for the less reaction time from the floor and the result of the physical characteristics that football needs. The investigations have shown that there is a significant and intense relationship between the sports branch, the specific movement patterns, the area (surface), the ball strikes, foot injuries and foot injuries and discomforts. Soccer players are faced with compelling movements during long periods of training and during competitions, in which the individual's feet are brought down. This inevitably changes the lower extremity biomechanics in the athlete, which in turn results in changes in the posture phase of the walk, affecting the foot pressure.

\section{Conclusion}

In our findings, it was determined that the pressures in the anterior region of the foot floor of the football players were lower than those of the control group and the other regions of their feet. Especially, it has been determined that the crampon used by footballers are inadequate to protect the foot floor and cannot prevent permanent changes in foot base pressure parameters. This situation should be considered as an important factor in terms of the athlete's foot comfort and performance. These results show that in the production of crampons, the parts to be noted on the soles of the feet must be concentrated on the heel and toe front. As a result, footballers have been forced to overload their soles with compulsive movements during training and matches for years and that demonstrates that athletes have a change in pressure zones and values in the foot well.

\section{References}

Aydos, L. (2011). Effect Of Wrestling On The Foot Sole Of Elite Wrestlers. International Journal Of The Physical Sciences, 6(13), 3143-3154.

Chen, H., Nigg, B. M., \& Dekoning, J. (1994). Relationship Between Plantar Pressure Distribution Under The Foot And Insole Comfort. Clinical Biomechanics, 9(6), 335-341. https://doi.org/10.1016/0268-0033(94)90062-0

Coté, J., Horton, S., MacDonald, D., \& Wilkes, S. (2009). The Benefits Of Sampling Sports During Childhood. Physical \& Health Education Journal, 74(4), 6.

Eils, E., Nolte, S., Tewes, M., Thorwesten, L., Völker, K., \& Rosenbaum, D. (2002). Modified Pressure Distribution Patterns In Walking Following Reduction Of Plantar Sensation. Journal Of Biomechanics, 35(10), 1307-1313. https://doi.org/10.1016/S0021-9290(02)00168-9

Eils, E., Streyl, M., Linnenbecker, S., Thorwesten, L., Volker, K., \& Rosenbaum, D. (2004). Characteristic Plantar Pressure Distribution Patterns During Soccer-Specific Movements. American Journal Of Sports Medicine, 32(1), 140-145. https://doi.org/10.1177/0363546503258932

Fong, D. T. P., Mao, D. W., Li, J. X., \& Hong, Y. (2008). Greater Toe Grip And Gentler Heel Strike Are The Strategies To Adapt To Slippery Surface. Journal Of Biomechanics, 41(4), 838-844. https://doi.org/10.1016/j.jbiomech.2007.11.001

Ford, K. R., Manson, N. A., Evans, B., Myer, G. D., Gwin, R. C., Heidt, R. S., \& Hewett, T. E. (2006). Comparison Of In-Shoe Foot Loading Patterns In Football Players On Natural Grass And Synthetic Turf. Medicine And Science In Sports And Exercise, 38(5), S.24-S25. https://doi.org/10.1016/j.jsams.2006.03.019

Ford, K. R., Manson, N. A., Evans, B. J., Myer, G. D., Gwin, R. C., Heidt, R. S., \& Hewett, T. E. (2006). Comparison Of In-Shoe Foot Loading Patterns On Natural Grass And Synthetic Turf. Journal Of Science And Medicine In Sport, 9(6), 433-440. https://doi.org/10.1016/j.jsams.2006.03.019

Ford, P. R., Ward, P., Hodges, N. J., \& Williams, A. M. (2009). The Role Of Deliberate Practice And Play In Career Progression In Sport: The Early Engagement Hypothesis. High Ability Studies, 20(1), 65-75.

https://doi.org/10.1080/13598130902860721

Kanatl1, U., Yetkin, H., Songür, M., Öztürk, A., \& Bölükbaşı, S. (2006). Yürüme Analizinin Ortopedik Uygulamaları. Türk Ortopedi Ve Travmatoloji Birliği Derneği Dergisi, 5(1-2), 53-59. 
Keen, M. (1993). Early Development And Attainment Of Normal Mature Gait. JPO: Journal Of Prosthetics And Orthotics, 5(2), 35. https://doi.org/10.1097/00008526-199304000-00004

Kunz, M. (2007). 265 Million Playing Football. Fifa Magazine, 7, 10-15.

Lord, S. R., Mclean, D., \& Stathers, G. (1992). Physiological Factors Associated With Injurious Falls In Older-People Living In The Community. Gerontology, 38(6), 338-346. https://doi.org/10.1159/000213351

NFLPA. (2006). NFL Players Playing Surfaces Opinion Survey. National Football League Players Association.

Park, J. H., Noh, S. C., Jang, H. S., Yu, W. J., Park, M. K., \& Choi, H. H. (2009). The Study Of Correlation Between Foot-Pressure Distribution And Scoliosis. 13th International Conference On Biomedical Engineering, Vols 1-3, 23(1-3), 974-978. https://doi.org/10.1007/978-3-540-92841-6_241

Queen, R. M., Haynes, B. B., Hardaker, W. M., \& Garrett, W. E. (2007). Forefoot Loading During 3 Athletic Tasks. American Journal Of Sports Medicine, 35(4), 630-636. https://doi.org/10.1177/0363546506295938

Renström, P., \& Johnson, R. J. (1985). Overuse Injuries In Sports. Sports Medicine, 2(5), 316-333. https://doi.org/10.2165/00007256-198502050-00002

Simon, S. R. (2004). Quantification Of Human Motion: Gait Analysis-Benefits And Limitations To Its Application To Clinical Problems. Journal Of Biomechanics, 37(12), 1869-1880. https://doi.org/10.1016/j.jbiomech.2004.02.047

Uzun, A. (2012). Investigate Of The Effect Of Basketball On The Sole Of Professional Basketball Players. Energy Education Science And Technology Part B: Social And Educational Studies, 4(4), 2611-2620.

Uzun, A. (2013). Distribution Of Sole Pressure In Female Football Players. Niğde University Journal Of Physical Education And Sport Sciences, 7(3), 230-241.

Wong, P., Chamari, K., Wisløff, U., \& Hong, Y. (2007). Higher Plantar Pressure On The Medial Side In Four Soccer-Related Movements. Brttish Journal Of Sports Medicine, 41(2), 93-100.

https://doi.org/10.1136/bjsm.2006.030668

\section{Copyrights}

Copyright for this article is retained by the author(s), with first publication rights granted to the journal.

This is an open-access article distributed under the terms and conditions of the Creative Commons Attribution license which permits unrestricted use, distribution, and reproduction in any medium, provided the original work is properly cited. 